\title{
Occipital Bone Fossa Associated with the Position of Rectus Capitis Posterior Minor Muscle
}

\author{
Fosa en el Hueso Occipital Asociado a la Posición del \\ Músculo Recto Posterior Menor de la Cabeza
}

Elisa Marinkovic* \& Paula Jorquera*

\begin{abstract}
MARINKOVIC, E. \& JORQUERA, P. Occipital bone fossa associated with the position of rectus capitis posterior minor muscle. Int. J. Morphol., 33(4):1319-1322, 2015.

SUMMARY: Rectus Capitis Posterior Minor muscle (RCPm) is one of the deepest and shorter muscles of the posterior region of the neck. RCPm arises from the posterior tubercle on the posterior arch of atlas and inserts on the squamous part of the occipital bone, inferior to the inferior nuchal line and lateral to the external occipital crest at midline. Based on their anatomical location, and their functional role, is considered to be a head extender muscle and an active element in the stabilization of the occipitoatlantal joint. During routine examination of the skulls, in the Morphology Laboratory of the Basic Biomedical Sciences Department, University of Talca, Chile, two unusual fossas were found in the squamous part of occipital bone, of an adult human skull of masculine sex. No other significant bony anomaly was noted, but it is observed that the elevations and depressions are well marked in the skull. The anatomical location of this fossa suggests a relationship with the RCPm muscle that is described in the same location of this finding. Therefore, it is postulated that prolonged improper posture from an early age, could generate a mechanical compression which would result in the finding fossas; this based on Wolff's law, which states that the bone tissue adapts to the mechanical demands placed on him.
\end{abstract}

KEY WORDS: Occipital Bone; Fossa; Anatomical variation; Rectus Capitis Posterior Minor muscle; Rectus Capitis Posterior Major muscle.

\section{INTRODUCTION}

Rectus Capitis Posterior Minor muscle (RCPm) is one of the deepest and shorter muscles of the posterior region of the neck, together with the Rectus Capitis Posterior Major (RCPM), Obliquus Capitis Superior, Obliquus Capitis Inferior, Multifidus Cervicis and Interespinales Cervicis muscles (Rouvière \& Delmas, 2006). It is classified as one of the suboccipital muscles (Latarjet \& Ruiz Liard, 2010) that connect atlas and axis vertebrae to the skull base (Gray, 1918).

$\mathrm{RCPm}$ arises from the posterior tubercle on the posterior arch of atlas and inserts on the squamous part of the occipital bone, inferior to the inferior nuchal line and lateral to the external occipital crest at midline (Gray; Testut \& Latarjet, 1982). Figure 1 shows schematically the structure previously described. Based on their anatomical location, and their functional role, is considered to be a head extender muscle (Gray; Testut \& Latarjet; Rouvière \& Delmas) and an active element that could influence the magnitude of flexion of the occipitoatlantal joint that occurs during voluntary retraction of the head and may contribute to stabilization of the occipitoatlantal joint during normal daily activities (Hallgren et al., 2014a).

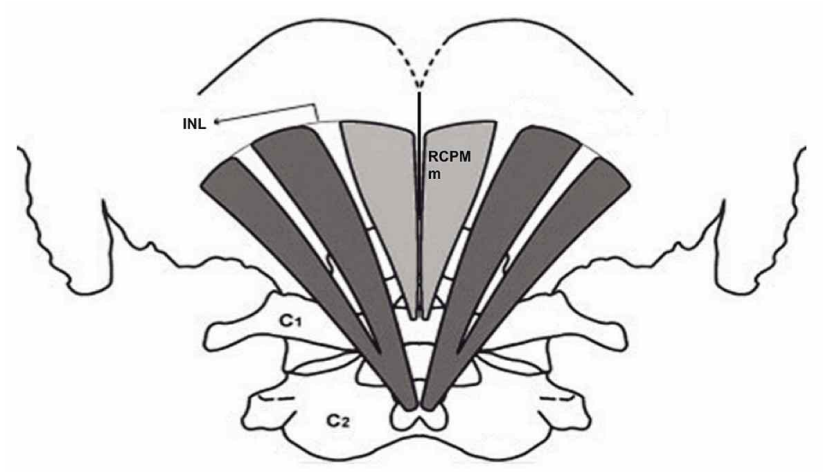

Fig. 1. Schematic illustration of Rectus Capitis Posterior Minor muscle (RCPMm). INL: Inferior Nuchal Line (Adapted from Tagil et al., 2005).

\footnotetext{
* Departamento de Ciencias Básicas Biomédicas, Facultad de Ciencias de la Salud, Universidad de Talca, Chile.
} 
Also a soft tissue connection has been described of this muscle and the posterior atlanto-occipital membrane, visualized in three distinct fiber-tipes: tendon-like, muscle-like and fascia-like bridges (Zumpano et al., 2006). Following the same idea, other authors point to the existence of a bridge of connective tissue between the RCPM muscle and dorsal spinal dura mater in the occipitoatlantal junction (Hack et al., 1995; Torres, 2008).

\section{CASE REPORT}

During routine examination of the skulls, in the Morphology Laboratory of the Basic Biomedical Sciences Department, Universidad de Talca, Chile, two unusual fossas were found in the squamous part of occipital bone, of an adult human skull of a male cadaver (Fig. 2). Both fossas had an oval shape and were located between inferior nuchal line superiorly and foramen magnum inferiorly, lateral to the external occipital crest at the insertion site of RCPm. The right fossa had a larger diameter parallel to the external occipital crest, while the left fossa had a larger diameter oblique from anterior to posterior and lateral to medial. Figure 2 shows that the right fossa had a larger diameter of $14 \mathrm{~mm}$. and a minor diameter of $13 \mathrm{~mm}$, while the left fossa had a larger diameter of $17 \mathrm{~mm}$. and a minor diameter of $12 \mathrm{~mm}$. Apparently, both fossas had a nutrient foramen in the superior quadrant, lateral to the external occipital crest (Fig. 2). No other significant bony anomaly was noted, but it is observed that both the elevations and depressions are well marked in the skull.

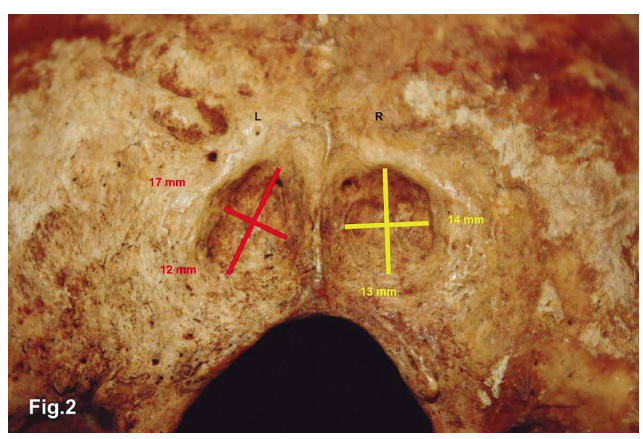

Fig. 2. Occiptal bone fossa and dimensions.

\section{DISCUSSION}

When searching for references associated with the case, no scientific literature related to this finding was found, suggesting that the presence of a fossa in the squamous part of occipital bone has not been described by the moment.

Classical literature has described numerous anatomic variations of the occipital bone. Some of the findings reference a third condyle and a bony spine on the anterior margin of the foramen magnum, along with nutrition foramina in the external occipital (Testut \& Latarjet). Also, variations in the formation of venous sinuses of the dura mater and the impressions they leave on the intracranial face of the occipital bone (Singh et al., 2004); a channel in the basilar part of the occipital bone (Chauhan et al., 2010) have been found. As described above, any of the variations related to the occipital bone refer a fossa in the squamous part of occipital bone.

The anatomical location of this fossa suggests a relationship with the RCPm muscle that is described in the same location of this finding. The dilemma is the presence of a fossa and not an elevation, considering the muscular traction produced by the muscle during head extension or the stabilization of the occipitoatlantal joint (Hallgren et. al., 2014a, 2014b).

A possible explanation of this result based on the limited scientific literature related to this muscle, could be that the fossa is a result of a muscular atrophy of the RCPmand excessive and prolonged compression of it muscular insertion, causing a cranial deformation of the occipital bone. All this is explained by the "Law of Wolff" (Wolff, 1986; Brand, 2010) that proposed that the effect of the mechanical forces acting through the bone lead to adjustments that causes bone adaptation (Hammer, 2015; Ruff et al., 2006). According to this principle, bone trabeculae follow lines of maximum internal force, allowing them to adapt to the efforts and tractions that is the bone subjected. Some trabeculae resist traction while others resist mechanical compressions; every change in bone shape or function, produces alterations in trabecular architecture and its external form. This law states that tension forces are the cause of bone growth, while compressive forces determine its atrophy. In conclusion, bone adapts to the mechanical demands placed on it (Nordin \& Frankel, 2004). Currently, the literature refers to the concept coined by Wolff as "functional bone adaptation", but this considers a greater amount of experimental analysis and specific characteristics, such as the genetic influence on bone development and the nature of the bone response to a mechanical compression (Ruff et al.).

The most accepted hypothesis for this case report, would be that the fossas were formed by mechanical compression of RCPm muscle, due to a hyper-extended cervical permanent position from an early age, such as in the case of a subject with neurological damage. As is known, bone during growth has a more ductile behavior, circumstance that can slow or block bone growth under compressive forces; while in the young 
bone, collagen fibers make it more vulnerable to compression (Hammer).

Analyzing the importance RCPm muscle, it contribute significantly to maintenance of a normal, neutral head posture as well as maintaining stability of the head during daily activities (Hallgren et al., 2014a, 2014b). Knowing this, head position will have an effect on this muscle and vice versa, founding that RCPm shows a strong effect in its activity product of changes in head position (Hallgren et al., 2014b).

Among the findings related to the suboccipital muscles, variations in the number of muscles in this region as supernumerary RCP muscles are described. An additional
RCPM muscle coupled with the absence of a RCPm muscle can result in a lack of muscular coordination in the suboccipital region, affecting the stability of the head and occipitoatlantal joint (Tagil et al., 2005; Nayak et al., 2011). Also, a relationship of the muscle with postural balance of the temporomandibular joint is described (Gillies et al., 1998).

Clinically, alterations of the suboccipital muscles can lead to compression of neural elements (Andary et al., 1998) and the role that RCPm muscle plays a role in head posture at cervical level and could be linked to cervicogenic headache, in some cases associated with muscle attachments to the dura mater (Nayak et al.; Hallgren et al., 2014b; Farmer et al., 2015).

MARINKOVIC, E. \& JORQUERA, P. Fosa en el hueso occipital asociado a la posición del músculo recto posterior menor de la cabeza. Int. J. Morphol., 33(4):1319-1322, 2015.

RESUMEN: El músculo Recto Posterior Menor de la Cabeza (RCPm) corresponde a uno de los músculos más profundos y cortos de la región posterior del cuello. Se origina en el tubérculo posterior del arco posterior de atlas y se inserta en la parte escamosa del hueso occipital, inferior a la línea nucal inferior y lateral a la cresta occipital externa a nivel de la línea mediana. En relación a su localización anatómica y a su funcionalidad, es considerado un músculo extensor de cabeza y un elemento activo en la estabilización de la articulación atlanto-occipital. Durante la inspección rutinaria de cráneos en el Laboratorio de Morfología del Departamento de Ciencias Básicas Biomédicas de la Universidad de Talca, se encontraron dos fosas inusuales en la porción escamosa de la cara exocraneal del hueso occipital de un cráneo humano adulto de sexo masculino. En la inspección no se registraron otros hallazgos, pero se observó que tanto las depresiones como elevaciones del cráneo eran muy marcadas. Durante la búsqueda de referencias bibliográficas asociadas al caso, no se encontró literatura científica relacionada a este hallazgo. La localización anatómica de esta fosa sugiere una relación con el músculo RCPm que se describe a este nivel. Por consiguiente, se postula que una postura inapropiada prolongada desde muy temprana edad, podría generar una compresión mecánica que formaría dichas fosas. Lo anterior basado en la Ley de Wolff que plantea que el tejido óseo se adapta a las demandas mecánicas impuestas sobre él.

PALABRAS CLAVE: Hueso Occipital; Fosa; Variación anatómica; Músculo recto posterior menor de la cabeza; Músculo recto posterior mayor de la cabeza.

\section{REFERENCES}

Andary, M. T.; Hallgren, R. C.; Greenman, P. E. \& Rechtien, J. J. Neurogenic atrophy of suboccipital muscles after a cervical injury: a case study. Am. J. Phys. Med. Rehabil., 77(6):545-9, 1998.

Brand, R. A. Biographical sketch: Julius Wolff, 1836-1902. Clin. Orthop. Relat. Res., 468(4):1047-9, 2010.

Chauhan, N. K.; Chopra, J.; Rani, A.; Rani, A. \& Srivastava, A. K. A bony canal in the basilar part of occipital bone. Int. J. Anat. Var., 3:112-3, 2010.

Farmer, P. K.; Snodgrass, S. J.; Buxton, A. J. \& Rivett, D. A. An investigation of cervical spinal posture in cervicogenic headache. Phys. Ther., 95(2):212-22, 2015.
Gray, H. Anatomy of the Human Body. 20th ed. Philadelphia, Lea \& Febiger, 1918.

Gillies, G. T.; Broaddus, W. C.; Stenger, J. M. \& Taylor, A. G. A biomechanical model of the craniomandibular complex and cervical spine based on the inverted pendulum. J. Med. Eng. Technol., 22(6):263-9, 1998.

Hack, G. D.; Koritzer, R. T.; Robinson, W. L.; Hallgren, R. C. \& Greenman, P. E. Anatomic relation between the rectus capitis posterior minor muscle and the dura mater. Spine (Phila $\mathrm{Pa}$ 1976), 20(23):2484-6, 1995.

Hallgren, R. C.; Pierce, S. J.; Prokop, L. L.; Rowan, J. J. \& Lee, A. $\mathrm{S}$. Electromyographic activity of rectus capitis posterior minor muscles associated with voluntary retraction of the head. Spine $J .$, 14(1):104-12, 2014a. 
Hallgren, R. C.; Rowan, J. J.; Bai, P.; Pierce, S. J.; Shafer-Crane, G. A. \& Prokop, L. L. Activation of rectus capitis posterior major muscles during voluntary retraction of the head in asymptomatic subjects. J. Manipulative Physiol. Ther., 37(6):433-40, 2014b.

Hammer, A. The paradox of Wolff's theories. Ir. J. Med. Sci., 184(1):13-22, 2015

Latarjet, M. \& Ruiz Liard, A. Anatomía Humana. 4a ed. Buenos Aires, Médica Panamericana, 2010. V. I.

Nayak, S. R.; Swamy, R.; Krishnamurthy, A. \& Dasgupta, H. Bilateral anomaly of rectus capitis posterior muscles in the suboccipital triangle and its clinical implication. Clin. Ter., 162(4):355-6, 2011.

Nordin, M. \& Frankel, V. H. Biomecánica básica del sistema musculo esquelético. $3^{\mathrm{a}}$ ed. Madrid, McGraw-Hill Interamericana, 2004.

Rouvière, H. \& Delmas, A. Anatomía Humana, Descriptiva, Topográfica y Funcional. Cabeza y Cuello. 11 a ed. Barcelona, Masson, 2005. V. I.

Ruff, C.; Holt, B. \& Trinkaus, E. Who's afraid of the big bad Wolff?: "Wolff's law" and bone functional adaptation. Am. J. Phys. Anthropol., 129(4):484-98, 2006.

Singh, M.; Nagashima, M. \& Inoue, Y. Anatomical variations of occipital bone impressions for dural venous sinuses around the torcular Herophili, with special reference to the consideration of clinical significance. Surg. Radiol. Anat., 26(6):480-7, 2004.

Tagil, S. M.; Ozcakar, L. \& Bozkurt, M. C. Insight into understanding the anatomical and clinical aspects of supernumerary rectus capitis posterior muscles. Clin. Anat., 18(5):373-5, 2005.

Testut, L. \& Latarjet, A. Tratado de Anatomía Humana. Barcelona, Salvat, 1982. V. I.

Torres, R. C. La columna cervical: Evaluación clínica y aproximaciones terapéuticas. Madrid, Médica Panamericana, 2008.

Wolff, J. The law of bone remodelling. Berlin, Springer-Verlag, 1986.

Zumpano, M. P.; Hartwell, S. \& Jagos, C. S. Soft tissue connection between rectus capitus posterior minor and the posterior atlanto-occipital membrane: a cadaveric study. Clin. Anat., 19(6):522-7, 2006.
Correspondence to:

Dra. Elisa Marinkovic G.

Departamento de Ciencias Básicas Biomedicas

Facultad de Ciencias de la Salud

Universidad de Talca

Av. Lircay $s / n$

Talca

CHILE

Email: emarinkovic@utalca.cl

Received: 26-02-2015

Accepted: 22-09-2015 